\title{
Metonymies and metaphors of sadness in the Old English vocabulary
}

\author{
Emilia Castaño Castaño and Isabel Verdaguer Clavera \\ University of Barcelona
}

\begin{abstract}
The aim of this paper is to explore the predominant metonymic and metaphoric conceptualizations of sadness in the Old English period. To this end, the Old English expressions for emotional distress recorded in The Old English Thesaurus and dictionary have been analyzed. Taking as a starting point the experiential grounding of emotion conceptualization, we first present experimental evidence in support of the role of somato-behavioral reactions in emotion recognition, affective state induction and emotional information processing and interpretation, and review the most common metonymic and metaphoric expressions for sadness in Modern English. Next, we analyze the Old English vocabulary for sadness and the interplay between embodiment and culture in the conceptualization and linguistic description of emotional distress. Such analysis makes it clear that in ancient times, as in present day English, sadness and psychological distress were also conceptualized in terms of unpleasant physical conditions such as illness, cold, darkness or heaviness. Consequently, a long-term diachronic trend in the conceptualization of sadness can be traced even though its linguistic realization and motivation have varied throughout time.
\end{abstract}

Keywords: Old English, conceptual metaphor and metonymy, emotions, sadness related vocabulary

\section{Introduction}

From the advent of the Cognitive Theory of Metaphor and Metonymy (Lakoff and Johnson 1980) in the early 1980s, the study of the cognitive representation of emotions and its embodied basis has become a highly topical subject in cognitive linguistics, psycholinguistics and cognitive science, which have investigated and empirically tested the experiential grounding of emotion conceptualization and affective judgments (Barcelona 1986, 1995, 2000; Deignan 2003, 2005; Glenberg, Havas, Becker \& Rinck 2005; Kövecses 1986, 1988, 1990, 1995, 2007; Stefanowitsch 
2004, 2006; among others). These studies suggest that thebody sensations that accompany emotions, or at least our subjective experience of them, are central to the way we think and talk about emotions.

From a psychological perspective, emotionsare largely seen as the result of the cognitive appraisal of current, past or imagined situations in relation to people's well-being, goals and expectations (Ellsworth \& Scherer 2003), which is manifested in action tendencies and physio-behavioral responses ${ }^{1}$ (Chen \& Bargh 1999; Ekman 2007). Thus, for example, cardiovascular, electrodermal and respiratory changes, along with conscious withdrawal, are among the most frequent body responses brought about by sadness ${ }^{2}$ (Kreibig, Wilhelm, Roth, \& Gross 2007; Seidel, Habel, Kirschner, Gur, \& Derntl 2010).

Table 1. Sadness body responses

\begin{tabular}{ll}
\hline Physiological variable & Response patterning in sadness \\
\hline Cardiovascular response & Decrease of ear pulse amplitude and finger temperature \\
Electrodermal response & High electrodermal activation \\
Respiratory response & Decrease of respiration rate \\
\hline
\end{tabular}

These data are in line with the folk theory of the bodily and behavioral effects of sadness, as deduced from people's self-reports on their subjective experience of this emotion. These reports show a consistent association between sadness and a series of unpleasant body symptoms and behavioral changes that include the sensation of having a lump in the throat, muscle tension, weak limbs, low felt temperature (Scherer, Wallbott \& Summerfield 1986; Scherer \& Wallbott 1994), tiredness, listlessness, slowing of the mind and body, downward body posture and forwards head bend (Izard 200o). ${ }^{3}$ Although self-reports of emotional experiences do not provide direct evidence of a link between body sensations and physiological responses, the words people use to describe their emotions show

1. Despite the controversy concerning the psychobiological universality of emotion patterning and the existence of unique and differential patterns of somatovisceral activity for each basic emotion, appraisal processes are thought to be key in the elicitation and differentiation of emotions.

2. For a complete review of the literature relating to physiological responses to fear, anger, disgust, sadness, and happiness, see Kreibig, S. D. (2010). Autonomic nervous system activity in emotion: A review. Biological Psychology, 84(3), 394-421.

3. The physiological origin of experienced body sensations is still questioned by those who hold a social view of emotions as culturally grounded patterns of feelings and behaviors followed in certain social contexts (Rimé \& Giovanni 1986; Philippot \& Rimé 1997). 
consistent enough patterns to suggest that our mental representation of emotions includes bodily and behavioral reactions.

Research on emotion recognition, affective state induction and emotional information processing and interpretation - including the comprehension of emotional language -, also points in this direction, since, as described in the following section, there is evidence that physio-behavioral input helps to recognize, induce and process emotion-related states and information.

\subsection{Literature review}

A large body of research has shown that emotion recognition and discrimination can be guided by facial expression (for a review see Matsumoto 2001; Matsumoto, Keltner, Shiota, O'Sullivan, \& Frank 2008). Thus, for example, the rise of the inner side of eyebrows and cheeks, along with the lowering of lip corners, is perceived as a manifestation of sadness, whereas happiness is related to lower eyelids and raised lip corners and cheeks. The connection between facial expressions and emotions has been corroborated now by several fMRI studies which have proved that the recognition of emotion from facial expressions engages motor, limbic, and somatosensory systems that are also active when experiencing that emotion (Enticott, Johnston, Herring, Hoy, \& Fitzgerald 2008; Wicker et al. 2003). These results support the claim that emotion recognition is mediated by a simulation mechanism triggered by the observation of emotion-related actions that leads to the spontaneous activation of the mirror neuron system (i.e., neurons that fire both when an action is executed and observed).

Along similar lines, other studies have proved that emotions can also be accurately inferred from body posture (Schouwstra \& Hoogstraten 1995; Coulson 2004). Sadness, for example, has been found to be consistently associated to a forwards head and chest bend while happiness is related to a backwards head and upright trunk (Coulson 2004). Such a connection between body states and emotion is also reinforced by the fact that certain neck, shoulder and arm muscles activate not only during the expression of emotions such as fear and anger but also when inferring these emotions from the observation of other people's bodily posture and movements (Huis In't Veld, Van Boxtel, \& de Gelder 2014)

A wealth of studies has also confirmed that specific emotional states - anger, fear, sadness, joy, confidence or pride - can be induced by manipulating expressive behavior. Thus, for instance, several studies have shown that after instructing participants to adopt an emotion-specific posture or facial expression, they reported experiencing that emotion and showed behaviors and changes in the autonomic nervous and cardiac system activity consistent with such an emotion (Boiten 1996; Duclos \& Laird 2001; Nair, Sagar, Sollers, Consedine, \& Broadbent 
2014). In a similar vein, it has also been proved that during intentional mimicry of emotion-related facial expressions neural activity extends beyond motor regions to reach brain areas typically involved in emotion (Lee, Josephs, Dolan, \& Critchley 2006; Vrticka et al. 2013) and that memories (i.e., the recall of positive or negative events) can be biased as a function of the body posture adopted by subjects (Riskind 1983; Wilson \& Peper 2004; Schnall \& Laird 2003).

On the other hand, the relationship between temperature and emotion has been verified by studies where the manipulation of physical warmth or coldness has been shown to induce feelings of social connection and loneliness (Ijzerman \& Semin 2009; Bargh \& Shalev 2012). In fact, there is evidence that the neural regions that detect physical warmth - the left VS and left middle insula - are also activated when detecting signs of social connection (Inagaki \& Eisenberger 2013).

Bodily states also seem to play a significant role in the comprehension of emotional language; in fact, evidence suggests a bidirectional connection between language and emotion in the sense that, on the one hand, emotional language understanding induces emotion-specific bodily changes and facial expressions (Niedenthal, Winkielman, Mondillon, \& Vermeulen 2009; Foroni \& Semin 2009) and, on the other, posture and facial expressions mediate language understanding (Havas, Glember, \& Rinck 2007) - either by boosting reading comprehension times or by hampering the processing of emotional language. Likewise, linguistic recall in psychiatric inpatients has also been proved to be swayed by body posture (Michalak, Mischnat, \& Teismann 2014), with more balanced recall of positive and negative words for patients with an upright posture than for patient with a slumped posture.

Other emotion-related behavioral attitudes such as approach or withdrawal also seem to be involved in language processing. Thus, for example, in rating tasks, shorter reaction times are observed for trials in which subjects make hand movements - towards or away - that are congruent with the valence of the words they are evaluating - positive or negative - (Chen \& Bargh 1999) or with the basic emotion conveyed by the stimuli - anger and sadness - (Alexopoulos \& Ric 2007; Mouilso, Glenberg, Havas, \& Lindeman 2007). Finally, as regards the embodied representation of emotions in terms of temperature, there is evidence that subjects presented with anger-related words bias temperature estimates towards hotter values (Wilkowski, Meier, Robinson, Carter, \& Feltman 2009).

In short, the literature review offered above supports the claim that perceptuallybased dimensions of experience such as emotionrelated bodily reactions and behaviors are used to understand the abstract concept of emotion. This might explain the ubiquitous useof expressions that map emotions onto physical reactions in Modern English. That is the case of sadness where bodily states such as slumped posture, reduced body temperature, physical weakness or physiolog- 
ical responses to lack of sunlightare often taken as a source domain. Some of those expressions show a metonymic pattern based on the stand-for relationship: EFFECTS OF EMOTION FOR EMOTION (Barcelona 2003; Kövecses 1990), as shown in Table 2.

Table 2. Metonymic expressions for sadness in Modern English

\begin{tabular}{lll}
\hline Source & Metonymy & Example \\
\hline Slumped posture & EFFECT OF EMOTION FOR & "His head drooped in sorrow" \\
EMOTION & \\
$\begin{array}{l}\text { Reduced body } \\
\text { temperature }\end{array}$ & $\begin{array}{l}\text { EFFET OF EMOTION FOR } \\
\text { EMOTION }\end{array}$ & "He felt chilled with sadness" \\
Weakness & $\begin{array}{l}\text { EFECT OF EMOTION FOR } \\
\text { FMCTION countenance }\end{array}$ & "My body weakened with sadness" \\
EFFECT OF EMOTION FOR & "He had a sad-eyed smile" \\
Crying and lamentation & $\begin{array}{l}\text { EMOTION } \\
\text { EFECT OF EMOTION FOR }\end{array}$ & $\begin{array}{l}\text { "His eyes filled with tears in the } \\
\text { EMOTION }\end{array}$ \\
\hline
\end{tabular}

Others, however, are metaphoric expressions where the subjective embodied experience of sadness seems to work along with other more general experiences and cultural values to ground our understanding of this emotion (see Table 3 ). Thus, for example, in the SADNESS Is COLD metaphor the descent in body temperature that goes with sadness, and may metonymically stand for this emotion, seems to be reinforced by an experiential correlation between bad weather conditions and a blue mood (Peña Cervel 1997), which helps the connection between sadness and cold. This metaphor, in turn, interacts with SADNESS IS DARK, where bad weather conditions, dark colors and sadness seem to be combined to ground the conceptualization of sadness as darkness (Peña Cervel 1997). This is not surprising considering that light and darkness are physiologically related to happiness and sadness, as shown by seasonal affective disorders (Stefanowitsch 2006). Moreover, as suggested by Antonio Barcelona $(1986,2000)$ and Joseph Grady and his coworkers (1997) the association between light conditions and emotions is underpinned by the fact that light is viewed as a positive phenomenon across cultures whereas darkness has negative connotations.

There are also particular manifestations of sadness such as loneliness, where coldness is experientially connected to physical separation or social rejection; in that case temperature and interpersonal closeness are conflated and mapped onto the concept of sadness, among other emotional states (Lakoff \& Johnson 1999; Ritchie 2013). 
Finally, the experiential grounding of SADNESS IS A BURDEN OR A PHYSICAL NUISANCE seems to combine the physical discomfort and drooping body posture that accompany sadness with more general experiential domains such as the bodily effects produced by weight related actions (Barcelona 1986).

Table 3. Metaphoric expressions for sadness in Modern English

\begin{tabular}{lll}
\hline Source & Metaphor & Examples \\
\hline Slumped posture & SADNESS IS DOWN & "He is feeling down these days" \\
$\begin{array}{l}\text { Reduced body temperature \& bad } \\
\text { weather }\end{array}$ & SADNESS IS COLD & "Her death chilled his soul" \\
Weakness and loss of energy & SADNESS IS ILLNESS & "He recovered from his \\
& & sorrow" \\
Drooping posture \& physical & SADNESS IS A BURDEN & "A heavy sadness fell upon \\
discomfort & /NUISANCE & him" \\
Lack of sunlight impact on mood & SADNESS IS DARK & "He is gloomy" \\
\hline
\end{tabular}

Hence, the synchronic analysis of the Modern English expressions for sadness seems to indicate that this conceptual domain is largely structured by a variety of metaphors and metonymies that resort to our subjective somato-behavioral experience to facilitate its understanding. Nevertheless, there exist certain linguistic expressions - see for example the terms melancholy and splenetic - whose motivation is synchronically opaque. In those cases, previous cultural beliefs (i.e., old physiology and psychology principles) and long term subjective associationsmust be taken into consideration to make these words semantically transparent. This posits the question of whether the conceptualization of sadness has remained diachronically constant along the history of English and highlights the need to consider the influence that previous cultural values and models, such as those embodying traditional beliefs about body functioning, have exerted on the conceptualization and linguistic description of sadness.

Since the early stages of the Cognitive Theory of Metaphor and Metonymy, most studies on metaphor and metonymy have been carried out from a synchronic point of view, with evidence taken from present-day data. Research from a diachronic perspective is more limited even though it has made a major contribution to the field. Thus, for example, diachronic studies have shown that many current cross-linguistic metaphors were also present in earlier stages of the language and have shed light on how metonymic and metaphoric senses develop (Allan 2008; Tissari 2008, 2010; Trim 2014; among others). Other studies have focused on historical and cultural variations (Anderson, Bramwell, \& Hough 2016; Allan 2006, 2010; Díaz-Vera 2014; Gevaert 2002; Györi 1998; Kövecses 2007; Mischler 2013; Stefanowitsch 2004; Trim 2010; Yu 1995, to name but a few) and 
have provided evidence that the basis of metaphor and metonymy may vary across time, languages and societies and that cultural models actively modulate the way a notion is conceptualized. The conceptualization of anger clearly illustrates this point since it shows diachronic variation (Geeraerts \& Gevaert 2008; Geeraerts, Gevaert, \& Speelman 2011; Gevaert 2001, 2005). Whereas in Present-day English anger is predominantly associated to heat (Kövecses 1986; Lakoff \& Kövecses 1987; Lakoff 1987), explained by our bodily reaction to anger, this conceptualization of anger has not been constant in the history of English due to the influence of cultural beliefs such as the Four Humors model.

In line with previous research on the historical conceptualization of emotions, in this paper we will explore which were the predominant metonymic and metaphoric conceptualizations of sadness in a period of English which was particularly fond of metaphors, Old English, and investigate the interplay between embodiment and culture in such conceptualization.

\section{Materials and method}

In this paper, we provide an exploratory analysis of the Old English expressions used to refer to the concept of sadness. The linguistic data have extracted from the Thesaurus of Old English; the online edition of the Bosworth-Toller Anglo-Saxon. After first searching for all the words referring to sadness in the Thesaurus of Old English (08.01.03) we have identified lexical overlapping between the semantic category of sadness and other semantic categories such as darkness, temperature and weight, among others, which provides evidence of a systematic connection between those semantic areas. Then, through corpus and dictionary searches we have identified which of those terms were metonymically or metaphorically used in the semantic category of sadness. The terms whose basic meaning was concrete but were contextually used in an abstract sense have been identified as metaphoric. Likewise, those terms that made reference to typical somato-behavioral reactions to sadness and stood for the emotion itself have been classified as metonymic. In this process, we have looked for metaphoric and metonymic links between semantic categories rather than individual metaphors alone, thus we have based our classification and results on the proportion of unique overlapping words between categories rather than on frequency criteria. The rationale behind this methodology, also used in the Mapping Metaphor with the Historical Thesaurus project, was to detect mappings between sadness and other domains of experience taking as starting point the observation that metaphors and metonymies can be identified from lexical overlap between semantic areas (Anderson, Bramwell, Hough 2016) 


\section{Findings and discussion: Sadness in the oE vocabulary}

Previous research on the expression of emotional distress in Old English has shown that the Anglo-Saxons had at their disposal a large repertoire of linguistic expressions to describe this feeling and that such expressions were able to differentiate between somatic and psychic distress (Nicholson 1995). Among the vocabulary that showed connotations of both general physical disturbance and mental pain there were expressions such as sār "sickness, bodily pain, sadness" and trega "pain, grief" (Nicholson 1995) but also sēoc "sick, ill, sad"; earfope "bodily pain, disease, affliction, trouble"; werig "wery, tired, exhausted, sad, grieved"; or mēpe "weary, exhausted with labor or disease, sad, weary in mind". Other terms such as hefigness "weight, burden, affliction, dullness and torpor" referred to more specific symptoms (i.e., lack of physical energy or enthusiasm) or identified emotional distress with terms that indicated discomfort in certain body parts, in particular the heart and the breast. Within the latter group compounds like heortsarnes literally "heart-soreness" or neaurness "chest discomfort, oppression and anxiety" can be listed. The Old English texts also abound in compounds that, even though nowadays do not refer to bodily states, in Old English could well describe bodily reactions to emotional distress such as the fast heartbeat that grief may cause. That is the case of breost-cearu "breast-care, heart-sorrow" (Ganze 2015). In fact, Ronald Ganze (2015:211) argues that Old English vocabulary was able to provide an accurate description of the bodily changes that take place when emotions such as grief and anger are present, "changes that themselves constitute the feelings of grief and anger".

In line with previous research, the analysis reported here shows that the Old English vocabulary related to sadness, just like Modern and Early Modern English vocabulary (Barcelona 1986; Tissari 2008, 2010), echoes some of the physical and behavioral effects that may go with this emotion. However, it also suggests that a comprehensive picture of the Old English conceptualization of sadness also involves awareness of the cultural and scientific traditions that prevailed at that moment, in particular the Four Humors Model, a scientific theory articulated by the Greek physician Hippocrates thatposited that the fluid content of the body consisting mainly of four humors: blood, phlegm, yellow bile and black bile regulated people's character and emotions (Radden 2000).

In the following section, we describe the prevalent conceptualizations of sadness in Old English (see Tables 4 and 5) as well as their potential motivation and linguistic realizations. The examples provided to illustrate our findings have been extracted from the Bosworth-Toller Anglo-Saxon Dictionary and the Old English Web Corpus. 
Even though there is scarce evidence of the use of somatic vocabulary to make reference to sadness (Nicholson 1995), the tendency to communicate psychological distress in the form of physical symptoms is confirmed by the Old English records. As illustrated below, Old English, like Modern English, relied on expressions stemming from the metonymic pattern: THE EFFECTS OF AN EMOTION STAND FOR THE EMOTION to express sadness, which yielded a system of metonymies that took physical discomfort, body-posture and temperature, crying and lamentation as their basis.

Table 4. Metonymic expressions for sadness in Old English

\begin{tabular}{lll}
\hline Source & Metonymy & Example \\
\hline Illness & SOMATIC EFFECT FOR EMOTION & Sēoc \\
Cold & SOMATIC EFFECT FOR EMOTION & frēorig \\
Drooping posture & SOMATIC EFFECT FOR EMOTION & hnipian \\
Crying & BEHAVIORAL EFFECT FOR EMOTION & hleōrdropa, teārig \\
Face countenance & BEHAVIORAL EFFECT FOR EMOTION & eärig-hleōr \\
Lamentation & BEHAVIORAL EFFECT FOR EMOTION & cwänian, wepan, wöpig, cwānig \\
Sigh & BEHAVIORAL EFFECT FOR EMOTION & sicettan, sicettung, sice \\
\hline
\end{tabular}

The adjective sēoc "sick", as indicated by Nicholson (1995), was used in Wulf and Eadwacer (1) to describe the bodily distress brought on by sadness. In compounds such as morgenseōc "sad at morning" and modseōcness "trouble in mind or heart", this adjective was also metaphorically used.

(1) Wulf, min Wulf, wena me pineseoce gedydon, pineseldcymas, murnende mod, nalesmeteliste. [DOE Corpus $0008(13)]$ "Wulf, my Wulf, the expectation of you, your rare visits, a sad mood, not want of food, made me sick."

In other texts, sadness was presented as concomitant to symptoms like cold (2), loss of appetite, sleeplessness and inability to focus (3):

(2) Ongonðahygegeomor, freorigondferðwerig, fusnegretan.

[DOE Corpus $0342(1156)]$

"He, mournful, sad/cold and weary of soul, resolved to greet the departing."

(3) wearðswasarigbot he slapon ne mihte on ealrceporenihte, ne he cetes ne gymde.

[DOE Corpus 0086 (320)]

"and became so sad that he was not able to sleep that night, nor he ate or heeded." 
By the same token, terms referring to body posture - now proved crucial in emotion recognition, induction and emotional language processing (see Section 1.1) - were also metonymically used to denote sadness. That is the case of the verb hnipian "to bow the head" that in Example (4) is interpreted as "looking gloomy":

(4) Bitereteärashīsymleālēton and hnipiendeeōdon.

[Hml. S. 23, 46]

"They continuously let go bitter tears and left drooping their heads."

Other behavioral effects of sadness, such as tear shedding, were reflected in adjectives like teārig "tearful"and other semantically related words such as hleōrdropa and wop-dropa both with the meaning "tear", which often accompanied the description of distressful emotional states (5). In the same vein, the Old English compound teārig-hleōr, literally "having the cheeks wet with tears", moved attention towards countenance as a window into inner emotions, as also did the word dreorighleōr "sad of countenance"(6). The relationship between emotion and countenance revealed by these terms seems sensible if, as stated in Section 1.1, it is taken into account that facial expressions are a key factor in emotional information processing and interpretation.

(5) Teagoryðumweol, hate hleordropan, ond on hreprewoegmiclemodceare.

[DOE Corpus 0392 (1340)]

"Tears welled up in floods, hot tears, and great sorrow carried in the heart."

(6) Nu scealtearighleor on westennewitodesbidan, hwonne of heortan hunger oððewulfsawle and sorgesomedabregde" [DOE Corpus 0704 (2276)] "Now, teary-faced I must await what is fated, when either hunger or the wolf may take from my heart both soul and sorrow together."

The expression of sorrow in terms of vocal laments was also reflected in the Old English lexicon by means of verbs such as cwānian "to bewail, to lament" (7) and adjectives like wōping "mournful, doleful" (8).

(7) Sum sceal, leōmenaleās, sārcwānian.

[Exon. 87 b]

"One, void of light, shall bewail his pain."

(8) Đoticwōpigscealteārummǣnan.

"That I lamenting should bewail with tears."

Finally, the slow and shallow pattern of breathing, usually associated to sadness (Kreibig, Wilhelm, Roth, \& Gross 2007; Seidel, Habel, Kirschner, Gur, \& Derntl 2010), metonymically stands for the very emotion in words such as sicettan "sigh", sicettung "sighing" and sice, as illustrated in the following example: 
(9) Icswince on minregranunge, and celceniht on minumbeddeicsice and wepe, and hwilum min beddwoete mid tearum.

[DOE Corpus oo54 (6.5)]

"I labor in my groaning and each night I sigh and weep on my bed and sometimes moisten my bed with tears."

In short, the Old English vocabulary for sadness clearly refer to somato-behavioral reactions that might well reflect the influence of both speakers' subjective experience of sadness effects and the Four Humors theory, which assumed that the feeling of sadness resulted from an excess of black bile, a fluid that was attributed the qualities of coldness, dryness and darkness. From this point of view sadness was seen as stemming from a health condition that among other symptoms caused are duction of body temperature, which might help the connection between sadness and illness and sadness and coldness illustrated by Examples (1) and (2).

Our search also shows that the Old English lexical field for sadness included metaphoric terms that clearly referred to the domain of temperature, darkness, physical pain and verticality. Such association between the target and source domains was made explicit in words which displayed both an abstract and concrete meaning, such as the Old English word sweorcan, meaning "to become dark", and also "to become sad".

Table 5. Metaphoric expressions for sadness in Old English

\begin{tabular}{lll}
\hline Source & Metaphor & Example \\
\hline Temperature & SADNESS IS COLD & frēorigmōd, wintercearig \\
$\begin{array}{l}\text { Natural } \\
\text { phenomena }\end{array}$ & $\begin{array}{l}\text { SADNESS IS A } \\
\text { (NATURAL) FORCE }\end{array}$ & hrēohmōd, windig \\
Darkness & SADNESS IS DARK & deorc, genip, sweorcan, drysmian ${ }^{*}$ \\
$\begin{array}{l}\text { Moving } \\
\text { downwards }\end{array}$ & SADNESS IS A & dreōsan, hēanmōd \\
Heaviness, load & SADNESS IS A & swǣr, sorgbyrðen, byrpen, hefigian, hefiglic \\
& BURDEN & \\
$\begin{array}{l}\text { Illness, physical } \\
\text { discomfort }\end{array}$ & $\begin{array}{l}\text { SADNESS Is } \\
\text { SICKNESs }\end{array}$ & $\begin{array}{l}\text { seōc, earfope, sār, sārian, sargian, langung, wērig, } \\
\text { modseōcness, morgenseōc, mēðe, prowian }\end{array}$ \\
\hline
\end{tabular}

* In this group should also be included the words sweorcendferhp "trouble in mind or heart"; gesweorenes "cloudiness, gloom, affliction, joylesness" and äsweorcan "to dim, darken, to look gloomy", which are morphologically derived from sweorc "darkness, mist".

The association between sadness and cold - already evidenced by the metonymic expressions analyzed above - was also metaphorically expressed by means of compounds such as frēorigmōd (frēorig "cold" + mōd "spirit, mood, disposition") "sad in mind or heart" where freōrig, which could also refer 
to physical temperature and be used in the sense "chilled" (10), acquired a metaphoric meaning (11).

(10) Ic woes mundum freōig

"I was with chilled hands."

[Andr. Kmbl. 982]

(11) He monge gehǣlde, ðe hine ādle gebundne gesōhtun, freōrigmōde

[Gú.860] "He healed many, who, oppressed with malady, sad in mind, sought him."

The underlying motivation for these metaphoric expressions could be a combination of somatic and cultural issues (see the previous section) reinforced by environmental factors (i.e., the association between bad weather conditions and sadness). This latter aspect could explain why sadness was also conceptualized as a storm or tempest in compounds like hrēohmōd "tempest-mood" used to denote sadness in mind or heart, and in the word windig, "windy", which expressed "distress".

The concept of sorrow was also connected to darkness in the words deorc "dark, sad, gloomy, miserable"; genip "darkness, affliction"; drysmian "to become dark, to be made sad, to mourn" and the lexical units derived from the root sweorc "darkness, mist". That is the case of sweorcan "to become dark and sad"; sweorcendferhp "trouble in mind or heart"; gesweorenes "joylesness" and āsweorcan "to look gloomy". In uhtceare "sorrow before dawn", sadness is related to what was popularly considered as the darkest hour to describe a special type of emotional distress, the insomnia that comes from grief and anxiety (Klinck 2001). The association between sadness and darkness that these words reflect could be grounded in environmental factors but it could also refer to the humoral model where blackness was a trait of both melancholy as a disease and melancholy as a temperament. Such link seems to be supported by the color of the fluid that was thought to cause melancholy, black bile. However, it is worth noting that, as pointed out by Simon (1978), bile is not actually black, thus this color attribution might result from the deeply rooted negative associations of the color black in Western culture.

Old English, like Modern English, conceptualized sadness as Down. According to Barcelona (1986), the slumped posture that usually goes with sadness acts as partial motivation for this metaphor, which can also be strengthened by the metaphor SADNESS IS A BURDEN. Verbs such as drēosan, which is recorded with the meaning "to sink (of spirits)" in the DOE and the compound hēanmōd, (hēan"low" + mōd "mood") "downcast, depressed, sad" are examples of this metaphor. On the other hand, terms such as byrben "burden, anxiety" or swēr "heavy, sad" were metaphorically used in sentences such as (12). Similarly, the compound sorgbyrðen "load of sorrow, burden of sorrow" clearly illustrates 
that the conceptualization of sorrow as a loadwas already part of the oe repertoire of metaphorical expressions for sadness.

(12) Sorhbipswǣrostbyrðen.

[Salm. Kmbl. 623]

"Anxiety is the heaviest burden."

Other terms also related to the notion of heaviness such as the adjectives hefig "heavy, grieved", hefiglic "weighty, sad" and the verb hefigian "to make heavy, to oppress, to grieve" referred to the feeling of sadness as well; this latter expression could also be connected to the conceptualization of sadness as physical discomfort and sickness, a mapping that is also present in words such as earfope "disease, trouble, affliction" and sār "bodily pain, sickness, sorrow, affliction", which denoted both physical pain (13) and distress (14). Likewise, the related verb sārian "to be sore, to be sad" and the nouns sargian "wound, grief" and langung "weariness, sadness" were recorded with concrete and abstract senses.

(13) Hē byð ðoessāreshāl

[Lchdm. i. 352, 2]

"He was cured of his wound."

(14) Is sāwlmīnsāres and yfelesgefylled

"My soul is full of sorrow and misery."

The verb ädlian "to be or become ill or weak; to languish" was metaphorically used in reference to the mind or soul, which suggests that both were conceptualized as entities that, like the body, can suffer disease and pain. This seems to be logical given that in medieval times there was a correlation between the physical and the emotional supported by the belief that the soul and the body were connected through a tertium quid called the spirit, which could be located in different parts of the body (Lewis 1964). It is worth noting here that in Old English the chest/ heart was consistently conceptualized as the locus of both feelings and thoughts (Lockett 2015).

Moreover, verbs such as prowian "to suffer", which was combined with the term lichoma "body" in sentences such as (15) to indicate physical suffering, was also used in combination with words such as gnorn "sadness, sorrow" meaning "to suffer sadness, affliction". All in all, these expressions reinforce the claim that sadness was conceptualized as physical pain maybe due to both people's somatic experience andthe pathological understanding of melancholy that the culturalscientific beliefs of the timesupported.

(15) Suā se līchomasuīðurūtanðrowað

[Past. 259, 22]

"As the body suffers more on the outside."

Finally, even among those terms whose meaning does not seem to have apparent metaphoric foundations, an etymological approach is able to uncover that they 
were metaphoric in origin as well. This is the case of sorg "grief, regret, pain, anxiety", which seems to have been derived from PIE ${ }^{*}$ swergh- "to worry, be sick" and was cognate with Lithuanian sergu "to be sick", Old Church Slavonic sraga "sickness" and Old Irish serg "sickness". Thus, sadness appears to be connected to illness here, as in the case of sārig "feeling grief, sorry, sorrowful, sad", which, even though in the Old English records is not found in the physical sense of "sore", was etymologically related to *sairaz "pain" (physical and mental) and *saira-"suffering, sick, ill".

The adjective dreorig "sad, sorrowful" is etymologically related to PIE *dhreu"to fall, flow, drip, droop" where the metaphor SADNESS Is Down seems to have operated. Finally, Old English caru or cearu "sorrow, anxiety, grief" evolved from Proto-Germanic *karo"lament; grief, care". In this case, the semantic development of the term in English seems to have evolved from one of the behavioral effect of sadness into the very emotion, since caru changed from "cry" to "lamentation" and finally "grief".

All in all, the data reported here suggests that the conceptualization of sadness in the Old English period relied on a combination of somatic, behavioral and environmental factors that reflected the intertwined influence of embodied experience, synchronic cultural beliefs and cross-cultural emotional symbolic associations such as the link between sadness and darkness.

\section{Conclusion}

Even though we are aware of the need of a larger Old English corpus for a quantitative study and for the exploration of other possible conceptualizations of sadness in the early periods of English, our data along with previous findings on the expressions of distress in oE (Nicholson 1995); Middle English (Díaz Vera 2011; Peters 2004), the Early Modern English period and present-day English (Tissari 2008, 2010; Kövecses 1986, 1988, 1995, 2000; Barcelona 1986; Stefanowitch 2006; among others) support a long-term metaphoric construal for the concept of sadness. As we have shown, Modern English speakers share with the Anglo-Saxons a similar network of conceptualizations of sadness. In ancient times, as in present day English, sadness and psychological distress were conceptualized in terms of unpleasant physical and environmental conditions such as illness, cold, heavinessor darkness. The conceptualization of sadness as physical pain is reflected by the adjective $s e \bar{c}$, which in addition to the concrete sense "sick, ill", could also mean "sad", in the same way as sār, which had both meanings "sickness, bodily pain" and "sadness" or trega that referred to "pain" and "grief". These concrete and abstract meanings can also be found in sargian, 
denoting both "wound" and "grief". The association between sadness and darkness is shown in the words deorc "dark, sad, gloomy, miserable", genip "darkness, affliction" or drysmian "to become dark, to be made sad, to mourn" while expressions such as frēorig "freezing, sad, sorrowful" and frēorigmōd "sad in mind or heart" connect the concept of sorrow with cold and low temperatures. Finally, sorrow was also conceptualized as a burden, as shown by terms such byrpen "burden, anxiety", swēer "heavy, sad", sorgbyrðen "load of sorrow, burden of sorrow" or hefigian "to make heavy, oppress, to grieve". These expressions reflect the mediating role of bodily experience and culture in the conceptualization of emotions and suggest that a baseline conceptualization of sadness based on metaphor and metonymy has existed throughout time despite diachronic and cultural variation, which allows to posit a "long-term diachronic trend" (Trim 2011:59) in its conceptualization.

\section{References}

Alexopoulos, T., \& Ric, F. (2007). The evaluation-behavior link: Direct and beyond valence. Journal of Experimental Social Psychology, 43(6), 1010-1016. https://doi.org/10.1016/j.jesp.2006.10.017

Allan, K. (2006). On groutnolls and nog-heads: A case study of the interaction between culture and cognition in intelligence metaphors. In A. Stefanowitsch \& S. Gries (Eds.),

Corpus-based approaches to metaphor and metonymy (pp. 175-190). New York: Mouton de Gruyter.

Allan, K. (2008). Metaphor and metonymy: A diachronic approach. Oxford: Wiley-Blackwell.

Allan, K. (2010). Tracing metonymic polysemy through time: MATERIAL FOR OBJECT mappings in the OED. In M.E. Winters, H. Tissari \& K. Allan (Eds.), Historical cognitive linguistics (pp. 163-196). Berlin: Mouton de Gruyter. https://doi.org/10.1515/9783110226447

Anderson, W., Bramwell, E., \& Hough, C. (Eds.). (2016). Mapping English metaphor through time. Oxford: Oxford University Press. https://doi.org/10.1093/acprof:0so/9780198744573.001.0001

Barcelona, A. (1986). On the concept of depression in American English: A cognitive approach. Revista Canaria de Estudios Ingleses, 12, 7-33.

Barcelona, A. (1995). Metaphorical models of romantic love in "Romeo and Juliet". Journal of Pragmatics, 24(6), 667-88. https://doi.org/10.1016/0378-2166(95)00007-F

Barcelona, A. (Ed.). (200o). Metaphor and Metonymy at the Crossroads: A Cognitive Perspective. Berlin and New York: Mouton de Gruyter.

Barcelona, A. (2003). On the plausibility of claiming a metonymic motivation for conceptual metaphor. In A. Barcelona (Ed.), Metaphor and metonymy at the crossroads: A cognitive perspective (pp. 31-58). Berlin: Mouton de Gruyter. https://doi.org/10.1515/9783110894677

Bargh, J. A., \& Shalev, I. (2012). The substitutability of physical and social warmth in daily life. Emotion, 12(1), 154-162. https://doi.org/10.1037/a0023527

Boiten, F. (1996). Autonomic response patterns during voluntary facial action. Psychophysiology, 33(2), 123-131. https://doi.org/10.1111/j.1469-8986.1996.tbo2116.x 
Bosworth, J., \& Toller, T.N. (Eds.). (1882). An Anglo-Saxon dictionary. Oxford: Clarendon Press. [Available at http://bosworth.ff.cuni.cz/]

Chen, M., \& Bargh, J. A. (1999). Consequences of automatic evaluation: Immediate behavioral predispositions to approach or avoid the stimulus. Personality and Social Psychology Bulletin, 25(2), 215-224. https://doi.org/10.1177/0146167299025002007

Clark Hall, J. R. (1916). A concise Anglo-Saxon dictionary. 2nd ed. Cambridge: Cambridge University Press.

Coulson, M. (2004). Attributing emotion to static body postures: Recognition accuracy, confusions, and viewpoint dependence. Journal of Nonverbal Behavior, 28(2), 117-139. https://doi.org/10.1023/B:JONB.0000023655.25550.be

Deignan, A. (2003). Metaphorical expressions and culture: An indirect link. Metaphor and Symbol, 18(4), 255-71. https://doi.org/10.1207/S15327868MS1804_3

Deignan, A. (2005). Metaphor and corpus linguistics. Amsterdam: John Benjamins. https://doi.org/10.1075/celcr.6

Díaz Vera, J. (2011). Conceptualizing emotional distress in Late Middle English medical texts. Revista de Lenguas para Fines Específicos, 17, 59-74.

Díaz-Vera, J. (Ed.). (2014). Metaphor and metonymy across time and culture. Berlin: Mouton de Gruyter.

DOE. (2008). The dictionary of Old English A to F. Toronto: DOE Project.

Duclos, S., \& Laird, J.D. (2001). The deliberate control of emotional experience through control of expressions. Cognition and Emotion, 15(1), 27-56. https://doi.org/10.1080/02699930126057

Ekman, P. (2007). The directed dacial action task. Emotional response without appraisal. In J. A. Coan \& J. B. Allen (Eds.), Handbook of emotion elicitation and assessment (pp. 47-53). New York: Oxford University Press.

Ellsworth, P.C., \& Scherer, K. R. (2003). Appraisal processes in emotion. In R. Davidson, K. R. Scherer, \& H. H. Goldsmith (Eds.), Handbook of affective sciences (pp. 572-595). New York: Oxford University Press.

Enticott, P., Johnston, P., Herring, S.E., Hoy, K.E., \& Fitzgerald, P. (2008). Mirror neuron activation is associated with facial emotion processing, Neuropsychologia, 46 (11), 2851-2854. https://doi.org/10.1016/j.neuropsychologia.2008.04.022

Etymology Online (n.d.). Retrieved from http://www.etymonline.com/

Foroni, F., \& Semin, G. (2009). Language that puts you in touch with your bodily feelings: The multimodal responsiveness of affective expressions. Psychological Science, 20(8), 974-980. https://doi.org/10.1111/j.1467-9280.2009.02400.x

Ganze, R. (2015). The neurological and physiological effects of emotional duress on memory in two Old English elegies. In A. Jorgensen, F. McCormack, \& J. Wilcox (Eds.), Anglo-Saxon emotions: Reading the heart in Old English literature, language, and culture (pp. 211-226). Surrey: Ashgate.

Geeraerts, D., \& Gevaert, C. (2008). Hearts and (angry) minds in Old English. In F. Sharifian, R. Dirven, N. Yu \& S. Niemeier (Eds.), Culture and language: Looking for the mind inside the body (pp. 319-347). Berlin: Mouton de Gruyter.

Geeraerts, D., Gevaert, C., \& Speelman, D. (2011). How anger rose: Hypothesis testing in diachronic semantics. In K. Allan \& J. A. Robinson (Eds.), Current methods in historical semantics (pp. 109-13). Berlin and Boston: Walter de Gruyter.

Gevaert, C. (2001). Anger in Old and Middle English: A "hot" topic? Belgian Essays on Language and Literature, 89-101. 
Gevaert, C. (2002). The evolution of the lexical and conceptual field of anger in Old and Middle English. In J. Díaz Vera (Ed.), A changing world of words. Studies in English historical lexicography, lexicology and semantics (pp. 275-299). Amsterdam and New York: Rodopi.

Gevaert, C. (2005). The ANGER IS HEAT question: Detecting cultural influence on the conceptualization of anger through diachronic corpus analysis. In N. Delbecque, J. van der Auwera \& D. Geeraerts (Eds.), Perspectives on variation: Sociolinguistic, historical, comparative (pp. 195-208). Berlin: Mouton de Gruyter.

Glenberg, A., Havas, D., Becker, R., \& Rinck, M. (2005). Grounding language in bodily states: The case for emotion. In D. Pecher \& R. A. Zwaan (Eds.), The grounding of cognition: The role of perception and action in memory, language and thinking (pp. 115-128). Cambridge: Cambridge University Press. https://doi.org/10.1017/CBO9780511499968.006

Grady, J., Oakley, T., \& Coulson, S. (1997). Blending and metaphor. In R. W. Gibbs \& G. J. Steen (Eds.), Metaphor in cognitive linguistics (pp. 101-124). Amsterdam: John Benjamins.

Györi, G. (1998). Cultural variation in the conceptualization of emotions: A historical study. In E. Tabakowska \& A. Athanasiadou (Eds.), Speaking of emotions: Conceptualisation and Expression (pp. 99-124). Berlin: Mouton de Gruyter.

Havas, D., Glenberg, A., \& Rinck, M. (2007). Emotion simulation during language comprehension. Psychonomic Bulletin \& Review, 14, 436-441. https://doi.org/10.3758/BF03194085

Huis in’t Veld, E. M. J., Van Boxtel, G. J. M., \& de Gelder, B. (2014). The body action coding system I: Muscle activations during the perception and expression of emotion. Social Neuroscience, 9(3), 249-264. https://doi.org/10.1080/17470919.2014.890668

Ijzerman, H., \& Semin, G. (2009). The thermometer of social relations: Mapping social proximity on temperature. Psychological Science, 20(10), 1214-20. https://doi.org/10.1111/j.1467-9280.2009.02434.x

Inagaki, T., \& Eisenberger, N. (2013). Shared neural mechanisms underlying social warmth and physical warmth. Psychological Science, 24(11), 2272-80. https://doi.org/10.1177/0956797613492773

Izard, C. (200o). Sadness. In A. Kazdin (Ed.), Encyclopedia of psychology (pp. 137-139). New York: Oxford University Press.

Klinck, A. (2001). The Old English elegies: A critical edition and genre study. Montreal: McGill-Queen's University Press.

Kövecses, Z. (1986). Metaphors of anger, pride, and love: A lexical approach to the study of concepts. Amsterdam: John Benjamins. https://doi.org/10.1075/pb.vii.8

Kövecses, Z. (1988). The language of love: The semantics of passion in conversational english. Lewisburg: Bucknell University Press.

Kövecses, Z. (1990). Emotion Concepts. Berlin and New York: Springer-Verlag. https://doi.org/10.1007/978-1-4612-3312-1

Kövecses, Z. (1995). Anger: Its language, conceptualization, and physiology in the light of cross-cultural evidence. In J. Taylor \& R. Maclaury (Eds.), Language and the cognitive construal of the world (pp. 181-196). Berlin: Mouton de Gruyter.

Kövecses, Z. (2000). Metaphor and emotion. New York and Cambridge: Cambridge University Press.

Kövecses, Z. (2007). Metaphor in culture: Universality and variation. Cambridge: Cambridge University Press. 
Kreibig, S. D. (2010). Autonomic nervous system activity in emotion: A review. Biological Psychology, 84(3), 394-421. https://doi.org/10.1016/j.biopsycho.2010.03.010

Kreibig, S. D., Wilhelm, F. H., Roth, W.T., \& Gross, J.J. (2007). Cardiovascular, electrodermal and respiratory response patterns to fear and sadness inducing films. Psychophysiology, 44(5), 787-806. https://doi.org/10.1111/j.1469-8986.2007.00550.x

Lakoff, G. (1987). Women, fire, and dangerous things: What categories reveal about mind. Chicago: The University of Chicago Press. https://doi.org/10.7208/chicago/9780226471013.001.0001

Lakoff, G., \& Johnson, M. (1980). Metaphors we live by. Chicago: The University of Chicago Press.

Lakoff, G., \& Johnson, M. (1999). Philosophy in the flesh: The embodied mind and its challenge to Western thought. New York: Basic Books.

Lakoff, G., \& Kövecses, Z. (1987). The cognitive model of anger inherent in American English. In D. Holland \& N. Quinn (Eds.), Cultural models in language and thought (pp. 195-221). Cambridge: Cambridge University Press. https://doi.org/10.1017/CBO9780511607660.009

Lee, T. W., Josephs, O., Dolan, R. J., \& Critchley, H.D. (2006). Imitating expressions: Emotion-specific neural substrates in facial mimicry. Social Cognitive and Affective Neuroscience, 1(2), 122-35. https://doi.org/10.1093/scan/nslo12

Lewis, C. S. (1964). The discarded image. Cambridge: Cambridge University Press.

Lockett, L. (2015). The limited role of the brain in mental and emotional activity according to Anglo-Saxon medical learning. In A. Jorgensen, F. McCormack \& J. Wilcox (Eds.), Anglo-Saxon emotions: Reading the heart in Old English literature, language, and culture (pp. 35-52). Surrey: Ashgate.

Matsumoto, D. (2001). Culture and emotion. In D. Matsumoto (Ed.), The handbook of culture and psychology (pp. 171-194). New York: Oxford University Press.

Matsumoto, D., Keltner, D., Shiota, M.N., O'Sullivan, M., \& Frank, M. (2008). What's in a face? Facial expressions as signals of discrete emotions. In M. Lewis, J. M. Haviland \& L. F. Barrett (Eds.), Handbook of emotions (pp. 211-234). New York: Guilford Press.

Michalak, J., Mischnat, J., \& Teismann, T. (2014). Sitting posture makes a difference-embodiment effects on depressive memory bias. Clinical Psychology and Psychotherapy, 21(6), 519-524.

Mischler, J. (2013). Metaphor across time and conceptual space. Amsterdam: John Benjamins. https://doi.org/10.1075/clscc.3

Mouilso, E., Glenberg, A., Havas, D., \& Lindeman, L. M. (2007). Differences in action tendencies distinguish anger and sadness after comprehension of emotional sentences. In D. S. McNamara \& G. Trafton (Eds.), Proceedings of the 29th annual Cognitive Science Society (pp. 1325-1330). Austin, TX: Cognitive Science Society.

Nair, S., Sagar, M., Sollers, J., Consedine, N., \& Broadbent, E. (2014). Do slumped and upright postures affect stress responses? A randomized trial. Health Psychology, 34(6), 632-41. https://doi.org/10.1037/heaoooo146

Nicholson, S. (1995). The expression of emotional distress in Old English prose and verse. Culture, Medicine \& Psychiatry, 19 (3), 327-338. https://doi.org/10.1007/BFo1381916

Niedenthal, P., Winkielman, P., Mondillon, L., \& Vermeulen, N. (2009). Embodiment of emotion concepts. Journal of Personality and Social Psychology, 96 (6), 1120-1136. https://doi.org/10.1037/a0o15574 
Peña Cervel, M.S. (1997). The role of the event structure metaphor and of image-schematic structure in metaphors for happiness and sadness. Miscelánea: A journal of English and American Studies, 18, 253-66.

Peters, H. (2004). The vocabulary of Pain . In C. Kay \& J. Smith (Eds.) Categorization in the history of English (pp. 193-220). Amsterdam: John Benjamins. https://doi.org/10.1075/cilt.261.11pet

Philippot, P., \& Rimé, B. (1997). The perception of bodily sensations during emotion: A cross-cultural perspective. Polish Psychological Bulletin, 28(2), 175-188.

Radden, J. (2000). The nature of melancholy: From Aristotle to Kristeva. New York: Oxford University Press.

Rimé, B., \& Giovanni, D. (1986). The physiological patterns of reported emotional states. In K. R. Scherer, H. G. Wallbott \& A. B. Summerfield (Eds.), Experiencing emotion: A cross-cultural study (pp. 84-97). Cambridge: Cambridge University Press.

Riskind, J.H. (1983). Nonverbal expressions and the accessibility of life experience memories: A congruency hypothesis. Social Cognition, 2(1), 62-86. https://doi.org/10.1521/soco.1983.2.1.62

Ritchie, L.D. (2013). Metaphor. Cambridge: Cambridge University Press.

Roberts, J., Kay, C., \& Grundy, L. (Eds.). (2000). A Thesaurus of Old English, 2 vols. Amsterdam: Rodopi.

Scherer, K. R., \& Wallbott, H. G. (1994). Evidence for universality and cultural variation of differential emotion response patterning. Journal of Personality and Social Psychology, 66 (2), 310-328. https://doi.org/10.1037/0022-3514.66.2.310

Scherer, K. R., Wallbott, H. G., \& Summerfield, A. B. (Eds.). (1986). Experiencing emotion: A cross-cultural study. Cambridge: Cambridge University Press.

Schnall, S., \& Laird, J.D. (2003). Keep smiling: Enduring effects of facial expressions and postures on emotional experience and memory. Cognition and Emotion, 17(5), 787-797. https://doi.org/10.1080/02699930302286

Schouwstra, S., \& Hoogstraten, J. (1995). Head position and spinal position as determinants of perceived emotional state. Perceptual and Motor Skills, 81(2), 673-674. https://doi.org/10.1177/003151259508100262

Seidel, E. M., Habel, U., Kirschner, M., Gur, R., \& Derntl, B. (2010). The impact of facial emotional expressions on behavioral tendencies in women and men. Journal of Experimental Psychology. Human Perception \& Performance, 36(2), 500-7. https://doi.org/10.1037/a0018169

Simon, B. (1978). Mind and madness in Ancient Greece: The classical roots of modern psychiatry. Ithaca, N. Y.: Cornell University Press.

Stefanowitsch, A. (2004). HAPPINESS in English and German: A metaphorical-pattern analysis. In M. Achard \& S. Kemmer (Eds.), Language, culture and mind (pp. 137-149). Stanford: CSLI Publications.

Stefanowitsch, A. (2006). Words and their metaphors: A corpus-based approach. In A. Stefanowitsch \& S. Gries (Eds.), Corpus-based approaches to metaphor and metonymy (pp. 61-105). Berlin and New York: Mouton de Gruyter. https://doi.org/10.1515/9783110199895

Tissari, H. (2008). On the concept of sadness: Looking at words in contexts derived from corpora. In B. Lewandowska-Tomaszczyk (Ed.), Corpus linguistics, computer tools, and applications - state of the Art (pp. 291-308). Frankfurt: Lang. 
Tissari, H. (2010). English words for emotions and their metaphors. In M.E. Winters, H. Tissari \& K. Allan (eds.), Historical cognitive linguistics (pp. 298-329). Berlin: Mouton de Gruyter. https://doi.org/10.1515/9783110226447

Trim, R. (2010). Conceptual networking theory in metaphor evolution: Diachronic variation in models of love. In M. Winters, H. Tissari \& K. Allan (Eds.), Historical cognitive linguistics (pp. 223-26o). Berlin: Mouton de Gruyter

Trim, R. (2011). Metaphor and the historical evolution of conceptual mapping. Basingstoke: Palgrave Macmillan. https://doi.org/10.1057/9780230337053

Trim, R. (2014). The interface between synchronic and diachronic conceptual metaphor. The role of embodiment, culture and semantic field. In J. Díaz Vera (Ed.), Metaphor and metonymy across time and cultures (pp. 95-120). Berlin: Mouton de Gruyter.

Vrticka, P., Simioni, S., Fornari, E., Schluep, M., Vuilleumier, P., \& Sander, D. (2013). Neural substrates of social emotion regulation: A fMRI study on imitation and expressive suppression to dynamic facial signals. Frontiers in Psychology, 4(95), 1-10. https://doi.org/10.3389/fpsyg.2013.00095

Wicker, B., Keysers, C., Plailly, J., Royet, J.P., Gallese, V., \& Rizzolatti, G. (2003). Both of us disgusted in my insula: the common neural basis of seeing and feeling disgust. Neuron, 40(3), 655-664. https://doi.org/10.1016/S0896-6273(03)00679-2

Wilkowski, M., Meier, B. P., Robinson, M. D., Carter, M.S., \& Feltman, R. (2009). Hot-headed is more than an expression: The embodied representation of anger in terms of heat. Emotion, 9(4), 464-477. https://doi.org/10.1037/a0015764

Wilson, V.E., \& Peper, E. (2004). The effects of upright and slumped postures on the recall of positive and negative thoughts. Applied Psychophysiology and Biofeedback, 29(3), 189-195. https://doi.org/10.1023/B:APBI.0000039057.32963.34

Yu, N. (1995). Metaphorical expressions of anger and happiness in English and Chinese.

Metaphor and Symbolic Activity, 10(2), 59-82. https://doi.org/10.1207/s15327868ms1002_1

\title{
Address for correspondence
}

\author{
Emilia Castaño Castaño \\ Department of English and German Philology \\ University of Barcelona \\ Gran Via de les Corts Catalanes, 585 \\ 08007 Barcelona \\ Spain \\ e.castano@ub.edu
}




\section{Co-author information}

Isabel Verdaguer Clavera

Department of English and German

Philology

University of Barcelona

i.verdaguer@ub.edu

Author Query

- Please provide a citation for the reference id "CITo116 (Bosworth, J., \& Toller, T.N. (Eds.). (1882)), CITo124 (Clark Hall, J.R. (1916)), CITo182 (Roberts, J., Kay, C., \& Grundy, L. (Eds.). (2000))" since citation is missing in the article. 